\title{
The BEST from Cambridge
}

\section{State and Provincial Society in the Early Modern Ottoman Empire \\ Mosul, 1540-1834 \\ Dina Rizk Khoury}

This comparative and broad-ranging book spans three centuries of Ottoman history. It offers a new interpretation of the relations between the central Ottoman empire and provincial Iraqi society in the early modern period, and demonstrates that, contrary to the accepted view, their military, fiscal and political links strengthened rather than weakened over the period.

Cambridge Studies in Islamic Civilization

59060-4 Hardback about $\$ 59.95$

\section{A History of Islamic Legal Theories \\ An Introduction to Sunni usul al-figh Wael B. Hallaq}

Wael B. Hallaq is already established as one of the most eminent scholars in the field of Islamic law. In his latest book, he traces the history of Islamic legal theory from its beginnings until the modern period. The book is the first of its kind in organization, approach to the subject, and critical apparatus, and as such will be an essential tool for the understanding of Islamic legal theory in particular and Islamic law in general.

59027-2 Hardback \$59.95

\section{The Persian Presence in the Islamic World \\ Richard G. Movannisian and Georges Sabagh, Editors}

In this volume, distinguished scholars reassess the Persian contribution to the Islamic world. The major essay by Ehsan Yarshater casts fresh light on that role, challenging the view that Islamic culture declined after the ninth century. In fact, he maintains, the adoption of Persian as the medium of literary expression meant that by the sixteenth century, Persian literary and intellectual paradigms had been cultivated in the greater part of the Islamic world.

Contributors: Georges Sabagh, Amin Banani,

Ehsan Yarshater, George Saliba, Annemarie Schimmel,

Gerhard Bowering, Oleg Grabar, C. Edmund Bosworth,

Garhard Doerfer

Levi Della Vida Symposia 13

59185-6 Hardback about $\$ 59.95$

\section{All the Pasha's Men}

Mehmed Ali, His Army and the Making of Modern Egypt

Khaled Fahmy

Khaled Fahmy offers a new interpretation of modern Egyptian history and the rise of Egyptian nationalism in a theoretically informed study. Basing his work on previously neglected archival material, the author demonstrates how Mehmed Ali built up the Egyptian army to further his own ambitions rather than as a means of gaining Egyptian independence. In this way, the book challenges traditionally held views about early nineteenth-century Egypt and the role of Mehmed Ali as the founder of modern Egypt. The book will be essential reading for students of the Middle East, Ottomanists, military historians and those interested in the construction of the modern nation state.

Cambridge Middle East Studies 8

56007-1 Hardback \$59.95

\section{Frontier Nomads of Iran}

A Political and Social History of the Shahsevan

\section{Richard Tapper}

Based on three decades of ethnographic fieldwork and documentary research, this book traces the political and social history of the Shahsevan, one of the major nomadic peoples of Iran. It is a dramatic story, recounting the mythical origins of the tribes, their unification as a confederacy and their eventual decline. Cambridge Middle East Studies 7

58336-5 Hardback about $\$ 69.95$

\section{On the Origins of the Ottoman Emperors} Theodore Spandounes Donald M. Nicol, Editor

The Turkish conquest of Constantinople in 1453 and the phenomenal expansion of the Ottoman Empire thereafter produced a ready market in the West for works about the origins, history and institutions of the Turks. Theodore Spandounes, himself of a Greek refugee family from Constantinople who had settled in Venice, was one of the first to publish such a work. Its final version, published in 1538 , was written in Italian. This book offers the first English translation of the complete text, with a historical commentary and explanatory notes.

58510-4 Hardback \$49.95 


\section{A JOURNAL OF IMPORTANCE}

\section{COMPARATIVE STUDIES \\ in

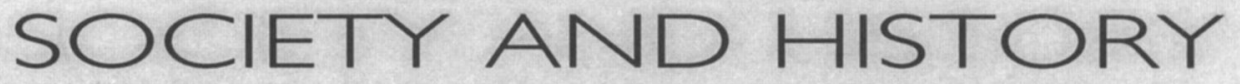

\section{Editor}

\section{RAYMOND GREW}

University of Michigan

Comparative Studies in Society and History is an international forum for scholars in the social sciences and humanities. Its articles present significant research on societies of every era from pre-history to the present and on every continent. CSSH brings together multidisciplinary research, cultural studies, and theory, emphasizing innovative work in the social sciences, especially anthropology, history, political science, and sociology. In each section, articles on a particular question are grouped together to stimulate comparison of diverse cases. Also included in each issue are CSSH Notes and book reviews.

Forthcoming contents include:

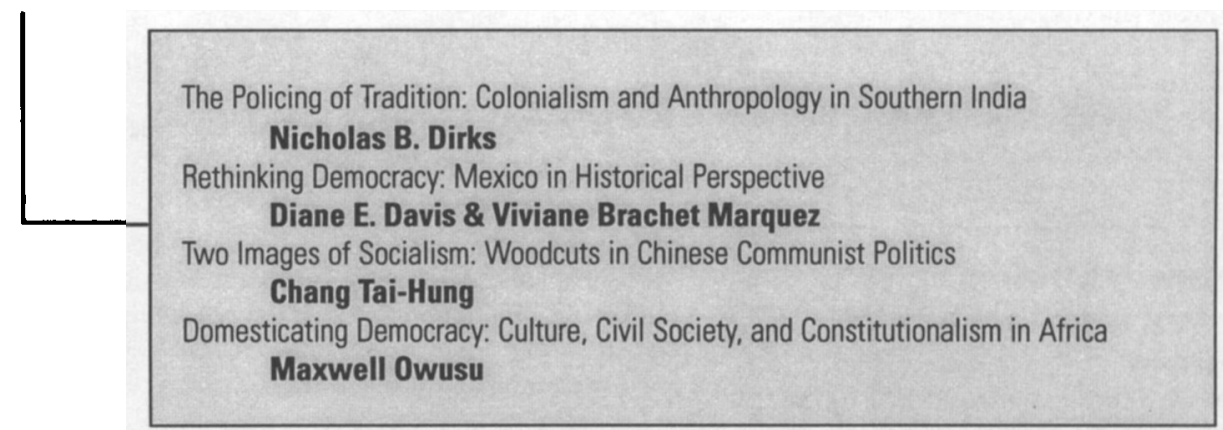

Quarterly (ISSN $0010-4 \mid 75$ )

Subscription to Volume 39 (1997):

Institutions $\$ 90.00$;

Individuals $\$ 37.00$.

\section{.




\section{NEW FROM CAMBRIDGE}

\section{Now in paperback...}

\section{Saladin}

The Politics of the Holy War

Malcolm Cameron Lyons and

D. E. P. Jackson

"... a distinguished and extremely well-researched book... reads easily and will be readily understood by the non-specialist."

- History Today

"...certainly the best book yet written about Saladin in English."

-The Times Literary Supplement

Saladin was one of the best known figures of the Middle Ages. The West accepted him as a hero; Islam was indebted to him for the recovery of Jerusalem. In this book Lyons and Jackson offer fresh information setting Saladin's life within the framework of his age.

Canto

58562-7 Paperback \$12.95

\section{Victory in the East}

A Military History of the First Crusade

\section{John France}

This book looks at the First Crusade as a military campaign and asks why it was successful. Modern writing about the crusade has tended to emphasize motivation and the development of the idea of the crusade, but its fate was ultimately decided on the field of battle. This book looks at the nature of war at the end of the eleventh century and the military experience of all the contending parties in order to explain its extraordinary success.

58987-8 Paperback $\$ 22.95$

\section{Hebrew Manuscripts at Cambridge University Library \\ A Description and Introduction \\ Stefan C. Reif}

This volume represents the first comprehensive guide to the Hebrew manuscripts held at the Cambridge University Library. The descriptions consider the standard biblical, rabbinic and liturgical material, but also cover scientific, poetic, philosophical and mystical content. Introductory essays are also included, together with extensive indexes, and a representative selection of photographed folios.

University of Cambridge Oriental Publications 52

58339-X Hardback $\$ 125.00$

\section{Overlooking Nazareth}

The Ethnography of Exclusion in a Mixed Town in Galilee

\section{Dan Rabinowitz}

Built on formerly Palestinian land, the Israeli new town of Natzerat Illit has a population of 25,000 Jewish Israelis and 3,500 Palestinians. This study investigates the ways in which both Israelis and Palestinians view issues of territory, territorial control and segregated education.

Cambridge Studies in Social and Cultural Anthropology

56361-5 Hardback \$59.95

56495-6 Paperback \$19.95

\section{The Thousand and One Nights} in Arabic Literature and

\section{Society}

\section{Richard C. Hovannisian and}

\section{Georges Sabagh, Editors}

The Thousand and One Nights has captivated audiences for centuries, conveying universal messages through the adventures of both historical and non-historical figures. Yet, in the field of literary criticism and scholarship, it has been marginalized in the tradition of high Arabic literature. This book defies this taboo by emphasizing the continuity rather than the compartmentalization of Arabo-Islamic culture.

Contributors: Andre Miguel, Jamel Eddine Bencheikh, Roy P. Mottahedeh, Fedwa Malti-Douglas, Seeger A. Bonebakker, Muhsin H. Mahdi, Stanislav Segert Levi Della Vida Symposia 12

57397-1 Hardback \$49.95

\section{Hierarchy and Egalitarianism in Islamic Thought Louise Marlow}

By analyzing a wide range of Arab and Persian literature, Louise Marlow demonstrates that Islam's initial orientation was markedly egalitarian, but the social aspect of this egalitarianism was soon undermined in the aftermath of Islam's political success.

Cambridge Studies in Islamic Civilization

56430-1 Hardback \$49.95

\begin{tabular}{c} 
Available in bookstores or from \\
UNIVERSITY PRESS \\
\hline West 20th Street, N.Y., NY 10011-4211 \\
Call toll-free 800-872-7423 \\
Web site: http://www.cup.org \\
MasterCard $/$ ISA accepted. \\
Prices subject to change.
\end{tabular}




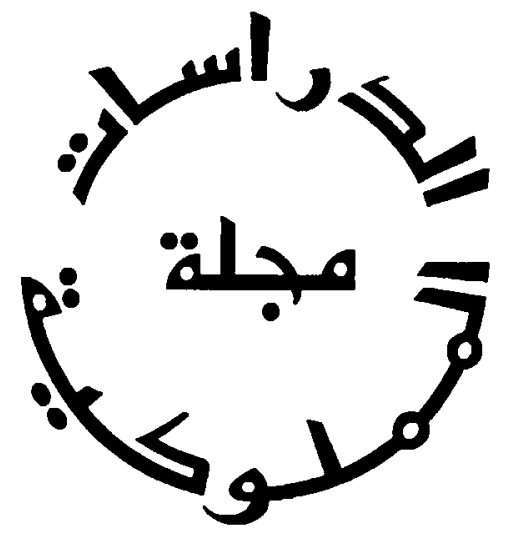

MAMLŪK STUDIES REVIEW

\section{The First Scholarly Journal Devoted Exclusively to Mamluk Studies}

\author{
Published by The Middle East Documentation \\ Center (MEDOC) \\ The University of Chicago
}

Mamlük Studies Review is an annual refereed journal devoted to the study of the Mamluk Sultanate of Egypt and Syria (648-922/1250-1517). The goals of Mamlūk Studies Review are to take stock of scholarship devoted to the Mamluk era, nurture communication within the field, and to promote further research by encouraging the critical discussion of all aspects of this important medieval Islamic polity. The joumal will include articles and reviews of recent books, as well as edited texts and translations of shorter Arabic source materials (waqf deeds, letters, fatāwá, etc.). Featured articles in Volume 2, 1998, include:

R. Stephen Humphreys, Ayyubids, Mamluks, and the Latin East in the Thirteenth Century

David Reisman, A Holograph MS of Ibn Qädi Shuhbah's "Dhayl"

Carl F. Petry, A Geniza for Mamluk Studies? Charitable Trust (Waqf) Documents as a Source for Economic and Social History

Doris Behrens-Abouseif, Sultan Qāytbāy's Foundation in Medina, the Madrasah, the Ribāt and the Dashishah

Sato Tsugitaka, The Proposers and Supervisors of al-Rawk al-Nāșiri in Mamluk Egypt Donald P. Little, Documents Related to the Estates of a Merchant and His Wife in Late Fourteenth Century Jerusalem

ISSN 1086-170X

Volumes 1 and 2 of Mamlük Studies Review are now available. The price for each volume is $\$ 90.00$.

Prepaid orders may be sent to: MAMLŪK STUDIES REVIEW, Middle East Documentation Center, 5828 South University Avenue, Pick Hall 201, Chicago, IL 60637 USA. Customers wishing to pay by credit card (Visa, Mastercard, American Express or Discover Card) may order from Seminary Co-op Bookstore, $5757 \mathrm{~S}$. University Ave., Chicago, IL 60637 USA (e-mail: books@semcoop.com). Fax: (773) 752-8507. 


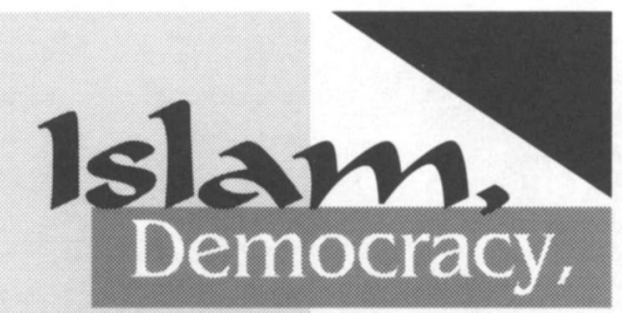

and the State in North Africa

\section{Edited by John P. Entelis}

In the late 1980s, misguided economic policies, bureaucratic mismanagement, political corruption, and cultural alienation combined to create a popular demand for change in Algeria, Morocco, and Tunisia. It seemed for a time that a new and more open politics would transform the region. Instead, authoritarian states mobilized to repress the populist opposition led by politicized Islamist movements. Analyzing developments over the last two decades from the perspectives of political culture and political economy, leading American scholars provide insights into the region's continuing political crisis.

\section{Contributors are} Lisa Anderson, Dale E. Eickelman, John P. Entelis, Clement M. Henry, Mark Tessler, Susan Waltz, John Waterbury, John O. Voll, and I. William Zartman.

Indiana Series in Arab and Islamic Studies 256 pages, 2 b\&w photos, 4 figs paper $\$ 15.95$ cloth $\$ 35.00$



\section{Science in Medieval Tslam} AN ILLUSTRATED INTRODUCTION By Howard R. Turner



"This book could well become the best means to introduce people to Islam's contributions to science, medicine, and philosophy. . . The wonderful illustrations make it even more understandable."

-Emory C.Bogle, Associate Professor of History, University of Richmond

During the Golden Age of Islam, Muslim philosophers and poets, artists and scientists, princes and laborers created a unique culture that has influenced societies on every continent. Here, Turner explores medieval Islamic accomplishments in cosmology, mathematics, astronomy, astrology, geography, medicine, natural sciences, alchemy, and optics. This survey of historic Muslim scientific achievements offers students and general readers a window into one of the world's great cultures, one which is experiencing a remarkable resurgence as a religious, political, and social force in our own time.

98 b\&w photos, 8 line drawings, 3 maps $\$ 19.95$ paperback, $\$ 40.00$ hardcover

\section{Iranian}

Intellectuals

in the

\section{Twentieth Century} By Ali Gheissari

Since the middle of the nineteenth century,

Iranian intellectuals have

been preoccupied by

issues of political and social reform, Iran's rela-

tion with the modern

West, and autocracy, or

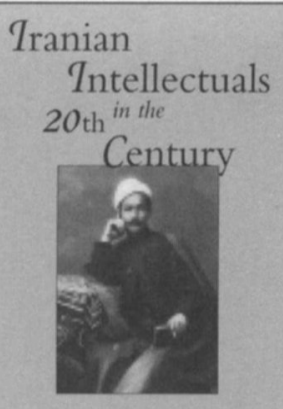

Ali Gheissari arbitrary rule. Drawing from a close reading of a broad array of primary sources, this book offers a thematic account of the Iranian intelligentsia from the Constitutional movement of 1905 to the post-1979 revolution.

$\$ 18.95$ paperback

At bookstores, or call 800-252-3206.

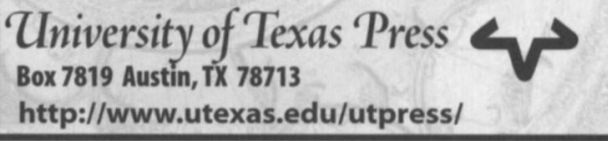




\section{EOTHEN Recent Titles on Cypous}

Salahi R. Sonyel

\section{Cyprus: The Destruction of a Republic} British Documents 1960-65

Important new light is shed by the recently released British documents, which also reveal the significant parts played by other powers in the decisions that led to the emergence of the Cyprus issue as it is today. (1997) ISBN 0906719453 (hardback) $\quad \mathbf{3 2 . 5 0} \$ 6250$ ISBN 0906719402 (pbk) $\quad$ f19.50 $\$ 35.00$

Michael Moran (editor)

\section{Rauf Denktash at the United Nations Speeches on Cyprus}

In a 100 page introduction the editor shows how in 1964 and 1965 the Greek Cypriot administration came to be recognised as the government of the Republic of Cyprus, and traces the effects of this fateful decision. The speeches to the UN by the Turkish Cypriot commmunity's leader, Rauf Denktash will be prime documents for historians. (1997) ISBN $090671950 \times$ (hardback) 378 pages

$£ 35.00 \$ 65.00$ ISBN 0900719550 (pbk) $\quad$ f19.95 \$39.95

\section{Clement H. Dodd}

\section{The Cyprus Issue: A Current Perspective}

A concise account of the conflict, including analysis of the UN 'Set of Ideas', the Confidence-building measures, and the implications of Cyprus's application to join the European Union. 37 pages Second ed (updated) 1996

ISBN $0906719356(\mathrm{pbk})$

Clement H. Dodd (editor)

\section{The Political, Social and Economic Development of Northern Cyprus}

Research papers constituting the first realistic assessment of politics, economy and society in this important but little known and largely unrecognized democratic state whose existence lies at the core of the Cyprus issue. Contributors: Şakir Alemdar, Clement H. Dodd, John Groom, John Martin, Behrooz Morvaridi, Zaim Necatigil, Ergün Olgun and Jonathan Warner. (1993) ISBN 0906719186 (pbk)

Vamik D Volkan and Norman Itzkowitz

\section{Turks and Greeks: Neighbours in Conflict}

A psychopolitical study of the historical legacy of suspicion and fear that underlies Turkish-Greek relations, and that inhibits solutions of present problems, including the Cyprus issue. 233 pages (1994) reprinted 1995

Major credit cards accepted

The Eothen Press

10 Manor Road, Hemingford Grey, Huntingdon, UK. PE18 9BX Tel/Fax 00441480466106

North American Agents: Paul \& Co. Inc. P.O Box 442 Concord, MA 01742 
The Journal of Semitic Studies was established in 1955 and since then has built up a reputation as one of the leading

JOURNAI, OF SEMITIC STUUIES international academic journals in its field. 'Semitic Studies' has always been understood by the editors to include the modern as well as the ancient Near (Middle) East, with special emphasis on research into the languages and literatures of the area. The editors continue to maintain the policy of ensuring that each volume contains items of interest to Orientalists and Biblical Scholars.

Extensive reviews of new books, as well as general review notices, remain a feature of the journal.

\section{A SELECTION OF RECENT AND FORTHCOMING ARTICLES}

Alasdair Livingstone The Akkadian Word for Barley: A Note from the Schoolroom.

William McKane Micah 2:1-5: Text and Commentary.

Sadok Masliyah Four Turkish Suffixes in Iraqi Arabic: -li, -lik, -siz, and -çi. Joseph Naveh A Syriac Amulet on Leather.

Yasir Suleiman The Simplification of Arabic Grammar and the Problematic Nature of the Sources.

Andras Hamori Mutanabbī's Painted Mosques.

Adrian Gully Arabic Linguistic Issues and Controversies of the Late Nineteenth and Early Twentieth Centuries.

\section{Order Form for Volume 42 (2 issues)}

a Institutions $\mathfrak{f}(6) / U S S I 29$ andividuals $\mathfrak{f} 45 /$ USS84 a Developing Countries $\mathfrak{E} 40 / \mathrm{USS} 75^{*}$

\section{$\square$ Please send me a free sample copy.}

$\square$ Please enter my 1997 subscription to Journal of Semitic Studies.

$\square$ I enclose a cheque payable to Oxford University Press.

$\square$ Please debit my Mastercard/Visa/American Express/Diners/JCB Card.

Card Number:

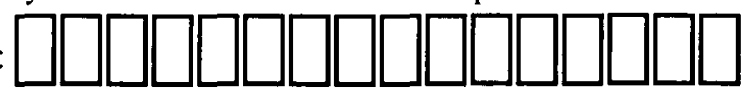

Expiry Date:

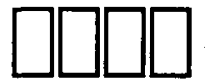

Signature.

- Pleaso note: $\mathrm{C}$ Sterling rates apply in UK and

Europo, USS rales elsowhere. Customers in tho EU

and Canada are sublect to thelr own local sales tax.

PLEASE PRINT DETAILS

Name.

Address

City/County

Postcode.

Oxford University Press Journals Marketing (XAS97) Great Clarendon Street, Oxford, OX2 6DP, UK. Tel: +44 (0)1865 267907 Fax: +44 (0)1865 267485 email.jnlorders@oup.co.uk 


\section{ENGLISH TRANSLITERATION SYSTEM CONSONANTS}

Column Headings: $\mathrm{A}=$ Arabic, $\mathrm{P}=$ Persian, OT = Ottoman Turkish, MT = Modern Turkish



\section{VOWELS}

ARABIC AND PERSIAN OTTOMAN TURKISH MODERN TURKISH

\begin{tabular}{|c|c|c|c|c|c|}
\hline Long I & & $\begin{array}{l}\overline{\mathbf{a}} \\
\overline{\mathbf{u}} \\
\overline{\mathbf{i}}\end{array}$ & $\begin{array}{l}\overline{\mathbf{a}} \\
\overline{\mathbf{u}} \\
\overline{\mathbf{I}}\end{array}$ & $\begin{array}{c}\text { words of Arabic } \\
\text { and Persian } \\
\text { origin only }\end{array}$ & $\begin{array}{l}\overline{\mathbf{a}} \\
\overline{\mathbf{u}} \\
\overline{\mathbf{i}}\end{array}$ \\
\hline Doubled & $\because$ & $\begin{array}{l}\text { iyy (final } \\
\text { form i }\end{array}$ & \multicolumn{2}{|c|}{$\begin{array}{l}\text { iy (final } \\
\text { form i) }\end{array}$} & iy (fina \\
\hline & ', & $\begin{array}{l}\text { uww (final } \\
\text { form ū), etc. }\end{array}$ & \multicolumn{2}{|c|}{ uvv } & uvv \\
\hline Diphthongs & 5 & au or aw & \multicolumn{2}{|c|}{ ev } & ev \\
\hline & 5 & ai or ay & \multicolumn{2}{|c|}{ ey } & ey \\
\hline Short & , & $\begin{array}{l}\sim a \\
\sim u\end{array}$ & \multicolumn{2}{|c|}{$\begin{array}{l}\text { a or e } \\
\text { u or ü }\end{array}$} & $\begin{array}{l}\text { a or } \mathbf{e} \\
\mathbf{u} \text { or } \mathbf{i}\end{array}$ \\
\hline & $=$ & $\sim i$ & \multicolumn{2}{|c|}{ o or ö } & $\begin{array}{l}\text { o or b } \\
\text { I or i }\end{array}$ \\
\hline
\end{tabular}

For Ottoman Turkish, authors may either transliterate or use the modern Turkish orthography. 


\section{Contributions and Editorial Correspondence}

Send article submissions to the Editorial Office (address on inside front cover). Articles submitted to the journal should not be, or have been, submitted elsewhere. Books for review should also be sent to the Editor for forwarding to the Book Review Editors. Unsolicited book reviews cannot be accepted for publication.

\section{Manuscript Preparation and Style}

General. An article must be in English, should not exceed 40 typewritten pages (including main text, notes, tables, and figure captions), and should be typed on $81 / 2^{\prime \prime} \times 11^{\prime \prime}$ or A4 white bond paper with ample margins on all sides. The entire manuscript-including notes, tables, and references-must be typed double-spaced and numbered consecutively. Title and author's name should be centered at the top of the first text page. Institutional affiliation and location should appear at the bottom of the last text page. The Editor may find it necessary to return manuscripts for reworking or retyping that do not conform to these requirements.

Text. Use a 5-character paragraph indent. Avoid hyphenating words at the end of lines. Do not use desk-top publishing features (e.g., right margin justification or bold and italic typefaces). Block indent long quotations (more than 50 words). Never cross-reference.

Endnotes and References. Notes must be numbered consecutively throughout the text, typed double-spaced in paragraph style, and grouped together as a unit following the text. Footnotes at the bottom of the text page are not permitted. Any acknowledgment of grant support, substantial assistance, etc., should be typed as an Author's Note above the first note. Provide the full name of the author as it appears on the publication. All titles in non-Roman alphabets (Arabic, Cyrillic, etc.) must be transliterated. Foreign titles in Roman alphabets should be capitalized as they would be in that particular language. An English translation of nonstandard language titles should be provided in parentheses after the title. The style of note citations should conform with the following examples:

'Stanford J. Shaw, History of Ottoman Empire and Modern Turkey, 2 vols. (New York: Cambridge University Press, 1977), Reform, Revolution and Republic: The Rise of Modern Turkey 1808-1975, 2:3-6.

${ }^{2} \mathrm{Jamil}$ M. Abun-Nasr, A History of the Maghrib in the Islamic Period, 3rd ed. (New York: Cambridge University Press, 1987), 10.

${ }^{3}$ Howard Crane, trans. and ed., Risāle-i Micmāríyye: An Early-Seventeenth-Century Ottoman Treatise on Architecture, Studies in Islamic Art and Architecture 1 (Leiden: E. J. Brill, 1987), 71.

${ }^{4}$ Martin Rein and Donald Schon, "Frame-Reflective Policy Discourse," in Social Sciences and Modern States, ed. Peter Wagner, Carol Hirschon Weiss, Björn Wittrock, and Hellmut Wollman (New York: Cambridge University Press, 1991), 262-89.

${ }^{5}$ Clifford Geertz, "Toutes Directions: Reading the Signs in an Urban Sprawl," International Journal of Middle East Studies 21 (August 1989): 291-306.

When references to the same work follow without interruption use ibid. When notes to the same work follow after interruption, use the author's last name and a shortened title of the book or article. Do not use op. cit:

\section{${ }^{6}$ Shaw, History of Ottoman Empire, 2:6.}

'Ibid., 1:10-52.

As a less-preferred alternative, authors may use the social science method of citation. In the text, cite author and year in pahttps://dpermtheses! OIn/ / author's full name, title, city of publication, publisher, and year. IJMES does not publish bibliographies.

Foreign Words and Transliteration. All Arabic words found in an unabridged dictionary (e.g., ulema, shaykh, qadi, Sunni, $\mathrm{Shi}^{\mathrm{c}} \mathrm{i}$, mihrab, minbar, madrasa, masjid, jami ${ }^{c}$, hadith, suq) should be treated as English words, that is, not underlined and without diacriticals. Contemporary names and places should be spelled as they are found in such standard publications as the New York Times. All other transliterated words and phrases should be underlined and all their diacriticals included throughout the text. Be sure to distinguish between the hamza, ${ }^{c}$ ayn, and the apostrophe in the text. No diacritical marks other than the hamza and the ${ }^{c}$ ayn should appear in any proper names (e.g., names of people, dynasties, places) and names of well-known literary works (Qur'an, Shahnama), except: works written in Arabic, Persian, and Ottoman Turkish and cited in transliteration in the notes must include diacriticals for both author and title.

Transliteration System. All non-Roman alphabets must be transliterated, and authors are responsible for the consistency and accuracy of their transliterations. For Arabic and Persian, IJMES uses the modified Encyclopaedia of Islam system: $q a f=q$ not $\mathbf{k} ;$ jim $=\mathbf{j}$ not $\mathbf{d j}$; roman double-letter equivalents are nol underlined; the $l$ of $a l$-is not assimilated to the following consonant; ta marbuta is rendered $a$ not $a h$; the adjectival -ya followed by ta marbuta is rendered -iyya. Except at the beginning of an English sentence or endnote, only proper names are capitalized. For Ottoman Turkish, use either the Encyclopaedia of Islam system or modern Turkish orthography. For treatment of common Turkish words, such as medrese, turbe, etc., follow the rules on anglicizing Arabic and Persian words.

Dates. IJMES does not use double dating. Use common era (A.D.) dates only, unless quoting from an original source, in which case use the date as quoted (hijra, solar, etc.) with the common-era equivalent in parentheses.

Tables and Figures. Tables and figures must be cited in the text, e.g., (see Table 1). They should be numbered consecutively in arabic numbers, captioned, and appear as a unit following the notes section. They cannot be interspersed in the text. Diagrams must be professionally rendered or computer generated; details should be large enough to remain legible at $50 \%$ reduction. Below-standard artwork will be returned to the author for replacement. All artwork must be numbered and labeled with the author's name and article title. For halftones or other illustrations, consult the editor.

\section{Publishing Information}

Production. The publisher reserves the right to copyedit manuscripts to conform to the journal's style, which follows the rules found in the Chicago Manual of Style. Spelling will be edited to conform to American usage. More substantial editing will be returned to the author for approval before publication.

The lead author will receive one set of proofs for the correction of typographical or factual errors only. No rewriting will be allowed in the proof stage. Authors must return the material to the editorial office within 48 hours of receipt or approval will be assumed.

Offprints. The lead author of an article (but not bookreview) will receive 50 free offprints of the article. Additional offprints may be purchased if ordered at the proof stage. Orders received after the issue is printed are subject to a $50 \%$ reprint surcharge.

Copyright and Originality. Submission of an article implies that it has not been simultaneously submitted or previously published elsewhere. Authors are responsible for obtaining permission to publish any material under copyright. Contributors will be asked to assign their own copyright, on certain 
URI RUBIN, The Eye of the Beholder: The Life of Muhammad as Viewed by the Early Muslims, a Textual Analysis (Valerie J. Hoffman)

The Eastern Arab Lands

Malik Mufti, Sovereign Creations: Pan-Arabism and Political Order in Syria and Iraq (Lisa Anderson)

Israel, Palestine, and the Arab-Israeli Conflict

Mordechai BAR-ON, In Pursuit of Peace: A History of the Israeli Peace Movement (David Levi-Faur)

Michael Gorkin and RafiQa Othman, Three Mothers, Three Daughters: Palestinian Women's Stories (Laurie A. Brand)

Annelies Moors, Women, Property and Islam: Palestinian Experiences 1920-1990 (Julie Peteet)

AdEL SAFTY, From Camp David to the Gulf: Negotiations, Language and Propaganda, and War (Fawaz A. Gerges)

IRA SHARKANSKy, Governing Jerusalem Again on the World's Agenda (Donna Robinson Divine)

$647-649$

North Africa

Nicole Grimaud, La Tunisie à la recherche de sa sécurité; Moncef DJAZIRI, Etat et société en Libye (Robert Mortimer)

William A. Hoisington, JR., Lyautey and the French Conquest of Morocco (Will Swearingen)

Deborah Kapchan, Gender on the Market: Moroccan Women and the Revoicing of Tradition (Mary Elaine Hegland)

Geoff Simons, Libya: The Struggle for Survival, 2nd ed. (Ronald Bruce St. John)

$654-655$

655-657

\section{Ottoman Empire}

Justin MCCARTHY, Death and Exile: The Ethnic Cleansing of Ottoman Muslims, 1821-1922 (Robert Olson)

DANIEl PANZAC, ED., Histoire économique et sociale de l'Empire ottoman et de la Turquie (13261960): Actes du sixième congrès international tenu à Aix-en-Provence du ler au 4 juillet 1992 (Virginia H. Askan)

\section{Afghanistan and the Caucasus}

FAROOKa GaUHARI, Searching for Saleem: An Afghan Woman's Odyssey (Audrey C. Shalinsky)

M. HASSAN KAKAR, Afghanistan: The Soviet Invasion and the Afghan Response, 1979-1982 (Robert L. Canfield)

Tadeusz Swietochowski, Russia and Azerbaijan: A Borderland in Transition (Robert O. Freedman)

664-665

\section{Literature and the Arts}

Alice TAYLOR, Book Arts of Isfahan: Diversity and Identity in Seventeenth-Century Persia (Anthony Welch)

Andreas Tietze and Joseph Yahalom, Ottoman Melodies, Hebrew Hymns: A 16th Century Cross-Cultural Adventure (Pinchas Giller)

ERRATUM 


\section{CONTENTS}

Articles

The Politics of Cultural Expression

Gayane Karen Merguerian and Afsaneh Najmabadi Zulaykha and Yusuf: Whose "Best Story"?

$485-508$

Sussan Siavoshi Cultural Policies and the Islamic Republic: Cinema and Book Publication

KamRan TAlattof Iranian Women's Literature: From Pre-Revolutionary Social Discourse to Post-Revolutionary Feminism

\section{Creating National Identities}

Nelida Fuccaro Ethnicity, State Formation, and Conscription in Postcolonial Iraq: The Case of the Yazidi Kurds of Jabal Sinjar

SEnzIL Nawid The State, the Clergy, and British Imperial Policy in Afghanistan during the 19th and Early 20th Centuries

Charles D. Smith "Imagined Identities, Imagined Nationalisms: Print Culture and Egyptian Nationalism in Light of Recent Scholarship." A Review Essay of Israel Gershoni and James P. Jankowski, Redefining the Egyptian Nation, 1930-1945, Cambridge Middle East Studies (New York: Cambridge University Press, 1995). Pp. 297

Book Reviews

The Middle East in Comparative Perspective

Augustus Richard Norton, Civil Society in the Middle East, vol. 2 (Clement M. Henry)

Carla Makhlouf Obermeyer, ed., Family, Gender, and Population in the Middle East: Policies in Context (Marcia Inhorn)

Bruce Allen Watson, Desert Battles: Comparative Perspectives (Douglas V. Johnson II)

\section{Religion in the Political Arena}

Dale F. Eickelman and James Piscatori, Muslim Politics (Robert D. Lee)

TERRY NARDIN, ED., The Ethics of War and Peace: Religious and Secular Perspectives (J. Patout Burns)

\section{Islamic History}

ShIRley Guthrie, Arab Social Life in the Middle Ages: An Illustrated Study (Jonathan P. Berkey)

WolfGang Kallfelz, Nichtmuslimische Untertanen im Islam: Grundlage, Ideologie und Praxis der Politik frühislamischer Herrscher gegenüber inren nichtmuslimischen Untertanen mit besonderem Blick auf die Dynastie der Abbasiden (749-1248) (Mark R. Cohen)

Bernard LewIS, The Middle East: A Brief History of the Last 2,000 Years (Richard W. Bulliet)

CARL F. Petry, Twilight of Majesty. The Reigns of the Mamlūk Sultans al-Ashraf Qāytbāy and Qãnșūh al-Ghawrï (Ulrich W. Haarmann)

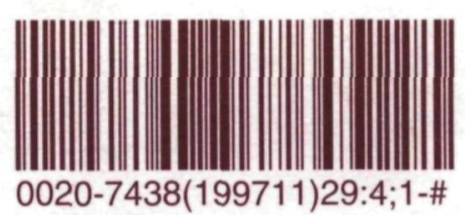

